\title{
Tolerance of Pseudomonas and Bacillus spp. to Cyahalothrin and Chlorpyrifos Pesticides
}

\author{
Williams, Janet Olufunmilayo*, Chibuike, Princess Mebom and Etim, Blessing Henry
}

Department of Microbiology, Rivers State University, Port Harcourt, Nigeria

*Corresponding author

\section{A B S T R A C T}

\begin{tabular}{|l|}
\hline K e y w o r d s \\
Chlorpyrifos \\
(organophosphate) \\
pesticide, \\
Cyahalothrin \\
(pyrethriod) \\
pesticide, Toxicity, \\
Pseudomonas \\
species and Bacillus \\
species \\
\hline Article Info \\
\hline Accepted: \\
28 March 2020 \\
Available Online: \\
10 April 2020 \\
\hline
\end{tabular}

The aim of this research is to determine the tolerance of Pseudomonas species and Bacillus species to Chloropyrifos and Cyahalothrin pesticides. The study area was the Rivers State University school farm, Faculty of Agriculture, Rivers State, Nigeria. The University farm is a large area of land that specializes in fish farming, livestock farming, poultry farming and all types of agricultural product farming. The university farm has also been used by students for research purposes. Standard microbiological procedures were used; Nutrient agar was prepared by weighing $28 \mathrm{~g}$ of nutrient agar into $1000 \mathrm{ml}$ of distilled water in Erlenmeyer flask. The medium was sterilized at $121^{\circ} \mathrm{C}$ for 15 minutes using the autoclave at 15 psi. centrimide agar was prepared by weighing $45.3 \mathrm{~g}$ of the agar and measuring $10 \mathrm{ml}$ of glycerol in $990 \mathrm{ml}$ of distilled water. The medium was heated with frequent agitation and boiled to completely dissolve the medium before autoclaving at $121^{\circ} \mathrm{C}$ for 15 minutes. Toxicity testing procedures were carried out by preparing a stock culture of the pesticide based on directions ( $8 \mathrm{ml}$ into $1000 \mathrm{ml}$ of distilled water) from which the concentrations used for this research was obtained $0 \%, 3.125 \%, 6.25 \%, 12.5 \%, 25 \%$ and $50 \%$ and tested on the soil sample for a period of 28 days. Samples were serially diluted and cultures were incubated at $35^{\circ} \mathrm{C}$ for 18 to 24 hours. $\mathrm{LC}_{50}$ was determined using SPSS version 2.0. Acute toxicity analysis was carried on pesticides (Chlorpyrifos and Cyahalothrin) in soil using Bacillus and Pseudomonas species as bio indicators. The toxicity results obtained in this study revealed that the pesticides (Chloropyrifos and Cyahalothrin) were toxic to the microorganisms. The results of median lethal concentration $\left(\mathrm{LC}_{50}\right)$ of the pesticides to the bio indicators (Pseudomonas and Bacillus species) which were determined by subtracting the value of the highest concentration used $(50 \%)$ from the sum of concentration difference, multiplied by mean percentage mortality and divided by the control (100). Results showed that Cyahalothrin exposed to Pseudomonas species for 28 days had 30.99\%, Chlorpyrifos exposed to Pseudomonas species had $12.83 \%$, Cyahalothrin exposed to Bacillus species had $12.77 \%$, Chloropyrifos exposed to Bacillus species had $10.77 \%$ (Tables $4.2 \mathrm{~b}$ to $4.5 \mathrm{~b}$ and Figure 4.5.). This indicated that Chlorpyrifos exposed to Bacillus species had the lowest median lethal concentration $(10.77 \%)$ and the highest toxic effect while Cyahalothrin exposed to Pseudomonas species had the highest median lethal concentration $\left(\mathrm{LC}_{50}\right)$ and the lowest toxic effect according to the report of Williams and Dilosi (2018); Kpormon and Douglas (2018). The results obtained in this research work revealed that pesticides (Chlorpyrifos and Cyahalothrin) have the ability to inhibit biological processes that are mediated by key environmental microorganisms such as Bacillus and Pseudomonas species etc in soil. Due to the effect observed on the survival rate of these organisms in this study, it indicates that these pesticides are capable of causing serious environmental pollution which will not only affect the microorganisms and their functions but also the abiotic components of the environment.

\section{Introduction}

Pesticides are substances that are meant to control pests, including weeds (USEPA, 2018). The term pesticide includes all of the following: herbicide, insecticides (which may include insect growth regulators, termiticides, etc.) nematicide, molluscicide, piscicide, avicide, rodenticide, bactericide, insect repellent, animal repellent, antimicrobial, and fungicide (Randall et al., 2014).

Most pesticides are intended to serve as plant protection products (also known as crop protection products) which in general protect plants from weeds, fungi, or insects (Randall et al., 2014). 
No segment of the population is completely protected against exposure to pesticides and the potentially serious health effects, though a disproportionate burden is shouldered by the people of developing countries and by high risk groups in each country (WHO, 1990).

The study of pesticide effects on non-target populations is an accepted strategy to evaluate its associated potential environmental risks. Among non-target populations, soil microorganisms are extremely important, since they play an essential role in nutrient turnover and maintaining generative capacity in agro-ecosystems (Bohlen et al., 2002).

The increased use of pesticides in agricultural soils causes the contamination of the soil with toxic chemicals (Muñoz-Leoz et al., 2013). When pesticides are applied, the possibilities exist that these chemicals may exert certain effects on non-target microorganisms such as Pseudomonas and Bacillus species which are of great importance in the soil (Zhao et al., 2013). The microbes play an important role in the soil ecosystem (Khan et al., 2010), and their functions (Khan et al., 2007) are very crucial in nutrient cycling and decomposition (Lorenzo et al., 2001).

\section{Materials and Methods}

\section{Place of study}

The study area was the Rivers State University school farm, Faculty of Agriculture, Rivers State, Nigeria. The University farm is a large area of land that specializes in fish farming, livestock farming, poultry farming and all types of agricultural product farming. Soil samples were collected from $8-10 \mathrm{~cm}$ depth with a sterile trowel from the plot of land where legumes are cultivated at the Rivers state university agricultural farm, and transferred into sterile polythene bags ensuring they were tied immediately to minimize contamination.

\section{Microbiological analysis}

\section{Serial dilution}

$9 \mathrm{ml}$ each of the prepared diluent (normal saline) was dispersed into different test tubes using a sterile pipette. The test tubes were plugged with cotton wool. Both the test tubes and its contents were sterilized in an autoclave at $121^{\circ} \mathrm{C}$ for 15 minutes. Tenfold serial dilution for total Pseudomonas and Bacillus count from soil sample was done by taking 1 gram of soil sample into the autoclaved $9 \mathrm{ml}$ test tubes containing diluents, swirled properly for homogeneity to give $10^{-1}$ dilution. This was repeated for $10^{-2}$ until dilutions were made up to $10^{-3}$. (Cheesebrough, 2006).

\section{Media preparation}

Nutrient agar was prepared by weighing $28 \mathrm{~g}$ of nutrient agar into $1000 \mathrm{ml}$ of distilled water in Erlenmeyer flask. The medium was sterilized at $121^{\circ} \mathrm{C}$ for 15 minutes using the autoclave at $15 \mathrm{psi}$. The medium was allowed to cool down to $45^{\circ} \mathrm{C}$ and $15 \mathrm{ml}$ of the meduim was poured into sterile petri dishes.

Centrimide agar was prepared by weighing $45.3 \mathrm{~g}$ of the centrimide agar and measuring $10 \mathrm{ml}$ of glycerol in $990 \mathrm{ml}$ of distilled water. The medium was heated with frequent agitation and boiled to completely dissolve the medium before autoclaving at $121^{\circ} \mathrm{C}$ for 15 minutes. The medium was allowed to cool and then poured into sterile petri dishes.

\section{Inoculation and incubation of cultures}

Inoculation of total Pseudomonas and Bacillus species was done by aseptically transferring an aliquot $(0.1 \mathrm{ml})$ of the dilution of $10^{-3}$ into properly dried nutrient agar plates and centrimide agar plates for Bacillus and Pseudomonas species in duplicates, spread evenly using bent glass rod and incubated at 
$35-37^{\circ} \mathrm{C}$ for 24hours respectively (Cheesebrough, 2006).

\section{Identification of pure culture}

The microorganisms used for this research wok were already identified species of Bacillus and Pseudomonas isolated from a soil sample.

\section{Preparation of chlopyrifos stock toxicants}

The chlopyrifos stock toxicant was prepared based on Manufacturers description $(800 \mathrm{ml}$ of pesticides into 100 litres of water). This toxicant was prepared with a volume of $8 \mathrm{ml}$ pesticides transferred into 1 litre of distilled water.

\section{Preparation of cyhalothrin stock toxicant}

The cyhalothrin stock toxicant was prepared based on manufacturer's prescription $(800 \mathrm{ml}$ of pesticides into 100 litres of water). This toxicant was prepared with a volume of $8 \mathrm{ml}$, pesticides transferred into 1 litre of distilled water.

\section{Preparation of toxicants (chlopyrifos and} cyhalothrin)

The toxicants were prepared aseptically by using different concentrations as: $3.125 \%$, $6.25 \%, 12.5 \%, 25 \%$ and $50 \%$ respectively of the toxicants. These concentrations were obtained aseptically by transferring $0.62 \mathrm{ml}$, $1.25 \mathrm{ml}, 2.5 \mathrm{ml}, 5 \mathrm{ml}, 10 \mathrm{ml}$ of the different pesticides stock solution into $19.38 \mathrm{ml}$, $18.75 \mathrm{ml}, 17.5 \mathrm{ml}, 15 \mathrm{ml}, 20 \mathrm{ml}$ of sterile distilled water respectively.

\section{Toxicity testing procedure}

This test was done in accordance with the method of Williams and Ogolo (10.2018) and Atunanya et al., (11. 2016). Ten millimeter (10ml) of the test organism was added to six plates containing $200 \mathrm{~g}$ of soil sample and different toxicant concentrations (3.125\%, $6.25 \%, 12.5 \%, 25 \%$ and $50 \%$ respectively).

One gram of soil samples was serially diluted to $10^{-3}$ and an aliquot $(0.1 \mathrm{ml})$ from each concentration of soil was then plated out using spread plate techniques.

Inoculation and spreading was done for 1,7 , 14, 21 and 28 days and incubated for 24 hours at room temperature $\left(28 \pm 2^{\circ} \mathrm{C}\right.$. $)$ after which the colonies on the plate were counted. The formula below was used to estimate the percentage log survival and mortality of the test organisms.

Percentage $(\%) \log$ survival $=\log \mathrm{c} \div \log \mathrm{e}$ $\mathrm{x} 100$

where

$\log c=\operatorname{logarithm}$ count in each toxicant concentration

$\log \mathrm{e}=\log$ arithm count in the control (zero concentration)

percentage $(\%) \log$ mortality $=100-\% \log$ survival (Williams and Ogolo 2018).

$\mathrm{LC} 50=\mathrm{LC} 100$

E conc.diff xmean \%mortality $1 \% \frac{\text { mortality }}{\text { Gheontrol }}$

\section{Results and Discussion}

\section{Physiochemical analyses results}

The results of physiochemical parameters analyzed in this study presented in table 1 below showed that the soil was acidic, deficient in calcium but rich in phosphate.

\section{Toxicity results}

The results of toxicity assay carried in this study are presented in Tables $2 \mathrm{a}$ to $5 \mathrm{~b}$ respectively. The tables show the percentage 
survival and Mortality of the test organisms exposed to various concentrations of the test organisms from day 1 to 28 while Table $2 b$ to $5 \mathrm{~b}$ show the results of median lethal concentration of the respective pesticides exposed to Bacillus and Pseudomonas species in soil.

Percentage logarithm survival of the respective organisms used is presented in
Figures 1 to 4 , while Figure 5 shows the comparative values of the median lethal concentrations of the two pesticides to the two test bacteria.

The table $2 \mathrm{~b}$ shows the median lethal concentration of Cyahalothrin from the percentage mortality of Pseudomonas species in soil. The median lethal concentration $\mathrm{LC}_{50}$ of Cyahalothrin in soil was $30.99 \%$.

Table.1 Physiochemical Analysis

\begin{tabular}{|l|l|l|}
\hline S/No. & Parameter & Result \\
\hline 1 & $\mathrm{pH}$ & 5.3 \\
\hline 2 & Temperature $\left({ }^{8} \mathrm{C}\right)$ & 26.7 \\
\hline 3 & Phosphate $(\mathrm{Mg} / \mathrm{kg})$ & 84.98 \\
\hline 4 & Magnesium $(\mathrm{ppm})$ & 1.51 \\
\hline 5 & Calcium $(\mathrm{ppm})$ & 0.01 \\
\hline 6 & Potassium $(\mathrm{ppm})$ & 1.38 \\
\hline 7 & Sodium $(\mathrm{ppm})$ & 2.29 \\
\hline 8 & Nitrate $(\mathrm{Mg} / \mathrm{kg})$ & 2.747 .25 \\
\hline 9 & Sulphate $(\mathrm{Mg} / \mathrm{kg})$ & $1,101.38$ \\
\hline
\end{tabular}

Table.2a Lethal toxicity results of cyahalothrin on Pseudomonas species in soil

\begin{tabular}{|l|c|c|c|c|c|}
\hline \multicolumn{1}{|c|}{ Time/Conc. (\%) } & $\mathbf{3 . 1 2 5}$ & $\mathbf{6 . 2 5}$ & $\mathbf{1 2 . 5}$ & $\mathbf{2 5}$ & $\mathbf{5 0}$ \\
\hline CONTROL & 100 & 100 & 100 & 100 & 100 \\
\hline Day 1 & & & & & \\
\hline \% survival & 58.37 & 53.06 & 51.6 & 48.57 & 43.67 \\
\hline \% mortality & 41.63 & 46.94 & 48.4 & 51.43 & 56.33 \\
\hline Day 7 & & & & & \\
\hline \% survival & 54.31 & 53.45 & 50.00 & 31.90 & 23.28 \\
\hline \% mortality & 45.69 & 46.55 & 50.00 & 68.10 & 76.72 \\
\hline Day 14 & & & & & \\
\hline \% survival & 74.62 & 31.82 & 30.68 & 11.36 & 0 \\
\hline \% mortality & 25.38 & 68.18 & 69.32 & 88.64 & 100 \\
\hline Day 21 & & & & & \\
\hline \% survival & 0 & 0 & 0 & 0 & 0 \\
\hline \% mortality & 100 & 100 & 100 & 100 & 0 \\
\hline Day 28 & & 0 & 0 & 0 & 0 \\
\hline \% survival & 0 & 0 & 0 & 0 & 100 \\
\hline \% mortality & 100 & 100 & 100 & 100 & \\
\hline
\end{tabular}


Table.2b Median lethal Concentration (LC50) of Cyahalothrin from Percentage Mortality of Pseudomonas species in Soil

\begin{tabular}{|c|c|c|c|c|}
\hline $\begin{array}{l}\text { Concentration } \\
(\%)\end{array}$ & \% Mortality & $\begin{array}{l}\text { Mean \% } \\
\text { mortality }\end{array}$ & $\begin{array}{c}\text { Conc. } \\
\text { different }\end{array}$ & $\begin{array}{l}\sum \text { of Conc. diff. } \times \\
\text { mean } \% \text { mortality }\end{array}$ \\
\hline 0 & $\mathbf{0}$ & 0 & 0 & \\
\hline 3.123 & 312.7 & 62.54 & 3.123 & 195.31 \\
\hline 6.25 & 361.7 & 72.34 & 3.123 & 225.91 \\
\hline 12.5 & 367.72 & 73.54 & 6.25 & 459.65 \\
\hline 25 & 408.17 & 81.63 & 12.5 & 1020.43 \\
\hline \multirow[t]{2}{*}{50} & 433.05 & & 25 & \\
\hline & & & & $\Sigma=1901.3$ \\
\hline \multicolumn{5}{|c|}{$\mathrm{LC}_{50}=\mathrm{LC}_{100}-\sum$ CONC. DIFF $\times$ MEAN \% MORTALITY } \\
\hline \multicolumn{5}{|c|}{$\%$ CONTROL } \\
\hline \multicolumn{5}{|c|}{$\mathrm{LC}_{50}=50-\underline{1901.3}$} \\
\hline \multicolumn{5}{|l|}{100} \\
\hline \multicolumn{5}{|c|}{$\mathrm{LC}_{50}=50-19.01$} \\
\hline $\mathrm{LC}_{50}=30.99 \%$ & & & & \\
\hline
\end{tabular}

Table.3a Lethal toxicity results of chlorpyrifos on pseudomonas species in soil

\begin{tabular}{|l|c|c|c|c|c|}
\hline \multicolumn{1}{|c|}{ Time/Conc. (\%) } & $\mathbf{3 . 1 2 5}$ & $\mathbf{6 . 2 5}$ & $\mathbf{1 2 . 5}$ & $\mathbf{2 5}$ & $\mathbf{5 0}$ \\
\hline \multicolumn{1}{|c|}{ CONTROL } & 100 & 100 & 100 & 100 & 100 \\
\hline Day 1 & & & & & \\
\hline \% survival & 65.04 & 59.35 & 54.07 & 51.63 & 48.78 \\
\hline \% mortality & 34.96 & 40.65 & 45.93 & 48.37 & 51.22 \\
\hline Day 7 & & & & & \\
\hline \% survival & 65.31 & 55.10 & 52.65 & 48.57 & 40.82 \\
\hline \% mortality & 34.69 & 44.90 & 47.35 & 51.43 & 59.18 \\
\hline Day 14 & & & & & \\
\hline \% survival & 44.78 & 39.93 & 34.33 & 69.22 & 25 \\
\hline \% mortality & 55.22 & 60.07 & 65.67 & & 75 \\
\hline Day 21 & & & & & \\
\hline \% survival & 0 & 0 & 0 & 100 & 100 \\
\hline \% mortality & 100 & 100 & 100 & 0 & 0 \\
\hline Day 28 & & & & 100 & 100 \\
\hline \% survival & 0 & 0 & 0 & & \\
\hline \% mortality & 100 & 100 & 100 & & \\
\hline
\end{tabular}


Table.3b Median lethal Concentration (LC50) of Chlorpyrifos from percentage mortality of Pseudomonas species in soil

\begin{tabular}{|c|c|c|c|c|}
\hline Concentration $(\%)$ & $\%$ mortality & $\begin{array}{l}\text { Mean \% } \\
\text { mortality }\end{array}$ & $\begin{array}{l}\text { Conc. } \\
\text { different }\end{array}$ & $\begin{array}{l}\sum \text { of Conc. diff. } \times \\
\text { mean } \% \text { mortality }\end{array}$ \\
\hline $\mathbf{0}$ & 0 & 0 & 0 & \\
\hline 3.123 & 324.87 & 64.74 & 3.123 & 202.91 \\
\hline 6.25 & 345.62 & 69.12 & 3.123 & 215.87 \\
\hline 12.5 & 358.95 & 71.79 & 6.25 & 448.69 \\
\hline 25 & 369.58 & 73.92 & 12.5 & 923.95 \\
\hline 50 & 385.4 & 77.08 & 25 & 1927 \\
\hline & & & & $\Sigma=3718.42$ \\
\hline \multicolumn{5}{|c|}{ LC $_{50}=$ LC $_{100}-\Sigma$ CONC. DIFF $\times$ MEAN $\%$ MORTALITY } \\
\hline & \multicolumn{4}{|l|}{$\%$ CONTROL } \\
\hline \multicolumn{5}{|l|}{$\mathrm{LC}_{50}=50-\underline{3718.42}$} \\
\hline \multicolumn{5}{|l|}{100} \\
\hline \multicolumn{5}{|l|}{$\mathrm{LC}_{50}=50-37.18$} \\
\hline $\mathrm{LC}_{50}=12.82 \%$ & & & & \\
\hline
\end{tabular}

Table.4a Lethal toxicity results of Cyahalothrin on Bacillus species in Soil

\begin{tabular}{|l|c|c|c|c|c|}
\hline \multicolumn{1}{|c|}{ Time/Conc. (\%) } & $\mathbf{3 . 1 2 5}$ & $\mathbf{6 . 2 5}$ & $\mathbf{1 2 . 5}$ & $\mathbf{2 5}$ & $\mathbf{5 0}$ \\
\hline \multicolumn{1}{|c|}{ CONTROL } & 100 & 100 & 100 & 100 & 100 \\
\hline Day 1 & & & & & \\
\hline \% survival & 57.49 & 54.66 & 52.63 & 47.37 & 40.48 \\
\hline \% mortality & 42.51 & 45.34 & 57.37 & 52.63 & 59.52 \\
\hline Day 7 & & & & & \\
\hline \% survival & 47.62 & 43.25 & 39.68 & 37.30 & 30.95 \\
\hline \% mortality & 52.38 & 57.75 & 60.32 & 62.70 & 69.04 \\
\hline Day 14 & & & & & \\
\hline \% survival & 41.24 & 37.23 & 31.75 & 25.19 & 17.15 \\
\hline \% mortality & 58.76 & 62.77 & 68.25 & 74.81 & 82.85 \\
\hline Day 21 & & & & & \\
\hline \% survival & 36.8 & 33.6 & 31.2 & 27.2 & 6.8 \\
\hline \% mortality & 63.2 & 66.4 & 68.8 & 72.8 & 93.2 \\
\hline Day 28 & & & & & \\
\hline \% survival & 22.5 & 15 & 11.25 & 7.5 & 0 \\
\hline \% mortality & 77.5 & 85 & 88.75 & 92.5 & 100 \\
\hline
\end{tabular}


Table.4b Median Lethal Concentration (LC50) of cyahalothrin from percentage mortality of Bacillus species in soil

\begin{tabular}{|c|c|c|c|c|}
\hline Concentration (\%) & $\%$ mortality & $\begin{array}{l}\text { Mean \% } \\
\text { mortality }\end{array}$ & $\begin{array}{c}\text { Conc. } \\
\text { different }\end{array}$ & $\begin{array}{l}\sum \text { of Conc. diff. } \times \\
\text { mean } \% \text { mortality }\end{array}$ \\
\hline 0 & $\mathbf{0}$ & 0 & 0 & \\
\hline 3.123 & 294.4 & 58.88 & 3.123 & 183.88 \\
\hline 6.25 & 317.3 & 63.46 & 3.123 & 198.19 \\
\hline 12.5 & 343.5 & 68.7 & 6.25 & 429.38 \\
\hline 25 & 355.4 & 71.08 & 12.5 & 888.5 \\
\hline 50 & 404.6 & 80.92 & 25 & 2023 \\
\hline & & & & $\Sigma=3722.95$ \\
\hline \multicolumn{5}{|c|}{ LC $_{50}=$ LC $_{100}-\Sigma$ CONC. DIFF. $\times$ MEAN $\%$ MORTALITY } \\
\hline & \multicolumn{4}{|l|}{$\%$ CONTROL } \\
\hline \multicolumn{5}{|l|}{$\mathrm{LC}_{50}=50-\underline{3722.95}$} \\
\hline \multicolumn{5}{|l|}{100} \\
\hline \multicolumn{5}{|l|}{$\mathrm{LC}_{50}=50-37.23$} \\
\hline $\mathrm{LC}_{50}=12.77 \%$ & & & & \\
\hline
\end{tabular}

Table.5a Lethal toxicity results of chlorpyrifos on Bacillus species in soil

\begin{tabular}{|l|c|c|c|c|c|}
\hline \multicolumn{1}{|c|}{ Time/Conc. (\%) } & 3.125 & 6.25 & 12.5 & 25 & 50 \\
\hline \multicolumn{1}{|c|}{ CONTROL } & 100 & 100 & 100 & 100 & 100 \\
\hline Day 1 & & & & & \\
\hline \% survival & 51.26 & 47.29 & 42.96 & 61.01 & 54.15 \\
\hline \% mortality & 48.74 & 52.71 & 57.04 & 38.99 & 45.85 \\
\hline Day 7 & & & & & \\
\hline \% survival & 26.86 & 24.79 & 37.19 & 31.40 & 24.79 \\
\hline \% mortality & 73.14 & 75.21 & 62.81 & 68.60 & 75.21 \\
\hline Day 14 & & & & & \\
\hline \% survival & 22.54 & 19.37 & 25.35 & 18.31 & 16.89 \\
\hline \% mortality & 77.46 & 80.63 & 74.65 & 81.69 & 83.11 \\
\hline Day 21 & & & & & \\
\hline \% survival & 18.62 & 17.24 & 15.17 & 100 & 100 \\
\hline \% mortality & 81.38 & 82.76 & 84.83 & & 0 \\
\hline Day 28 & & & & 0 & 0 \\
\hline \% survival & 14.92 & 12.20 & 8.47 & 100 & 100 \\
\hline \% mortality & 85.08 & 87.80 & 91.53 & & \\
\hline
\end{tabular}


Table.5b Median lethal concentration (LC50) of chlorpyrifos from percentage mortality of Bacillus species in soil

\begin{tabular}{|c|c|c|c|c|}
\hline Concentration (\%) & $\begin{array}{c}\% \\
\text { mortality }\end{array}$ & $\begin{array}{l}\text { Mean \% } \\
\text { mortality }\end{array}$ & Conc. different & $\begin{array}{l}\sum \text { of Conc. diff. } \times \\
\text { mean } \% \text { mortality }\end{array}$ \\
\hline $\mathbf{0}$ & O & 0 & 0 & \\
\hline 3.123 & 365.8 & 73.16 & 3.123 & 228.48 \\
\hline 6.25 & 379.11 & 75.82 & 3.123 & 236.79 \\
\hline 12.5 & 370.86 & 74.17 & 6.25 & 463.58 \\
\hline 25 & 389.28 & 77.86 & 12.5 & 973.2 \\
\hline 50 & 404.17 & 80.83 & 25 & 2020.85 \\
\hline & & & & $\Sigma=3922.9$ \\
\hline \multicolumn{5}{|c|}{ 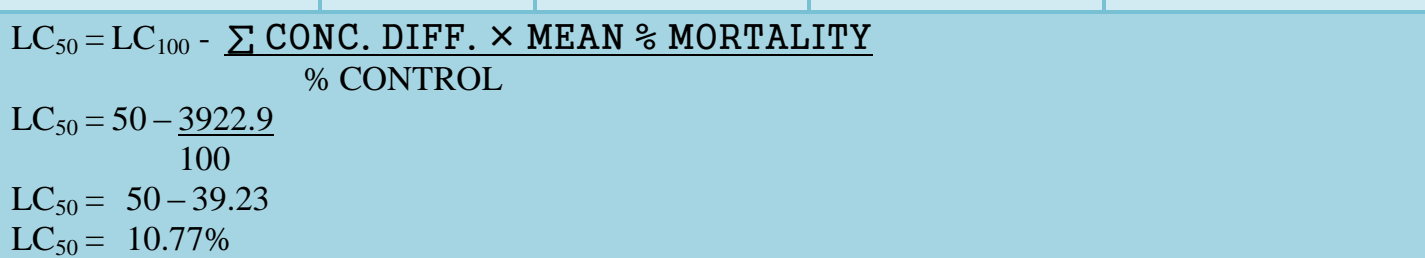 } \\
\hline
\end{tabular}

Figure.1 Percentage log Survival of Pseudomonas spp Exposed to Various Concentrations of Cyahalothrin

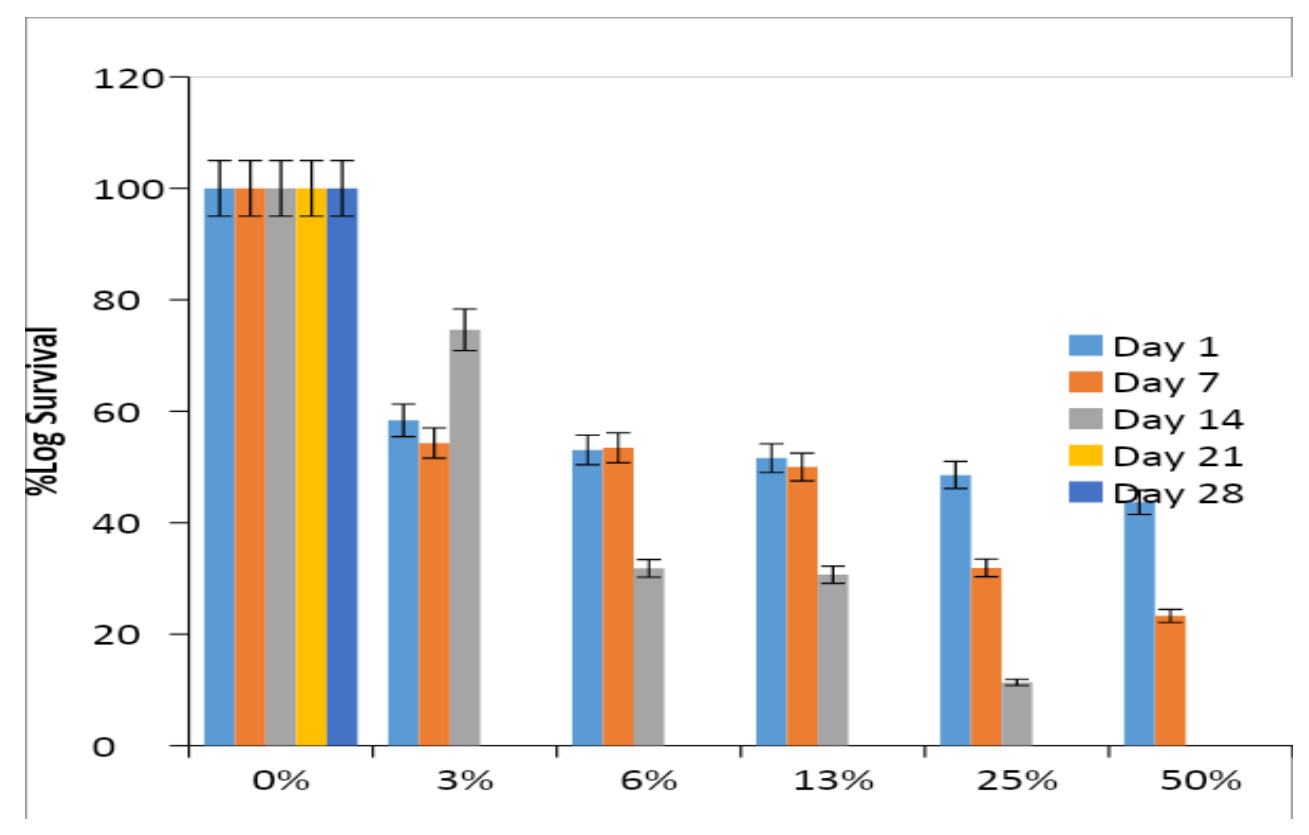


Figure.2 Percentage log survival of Pseudomonas species exposed to various concentrations of chlorpyrifos

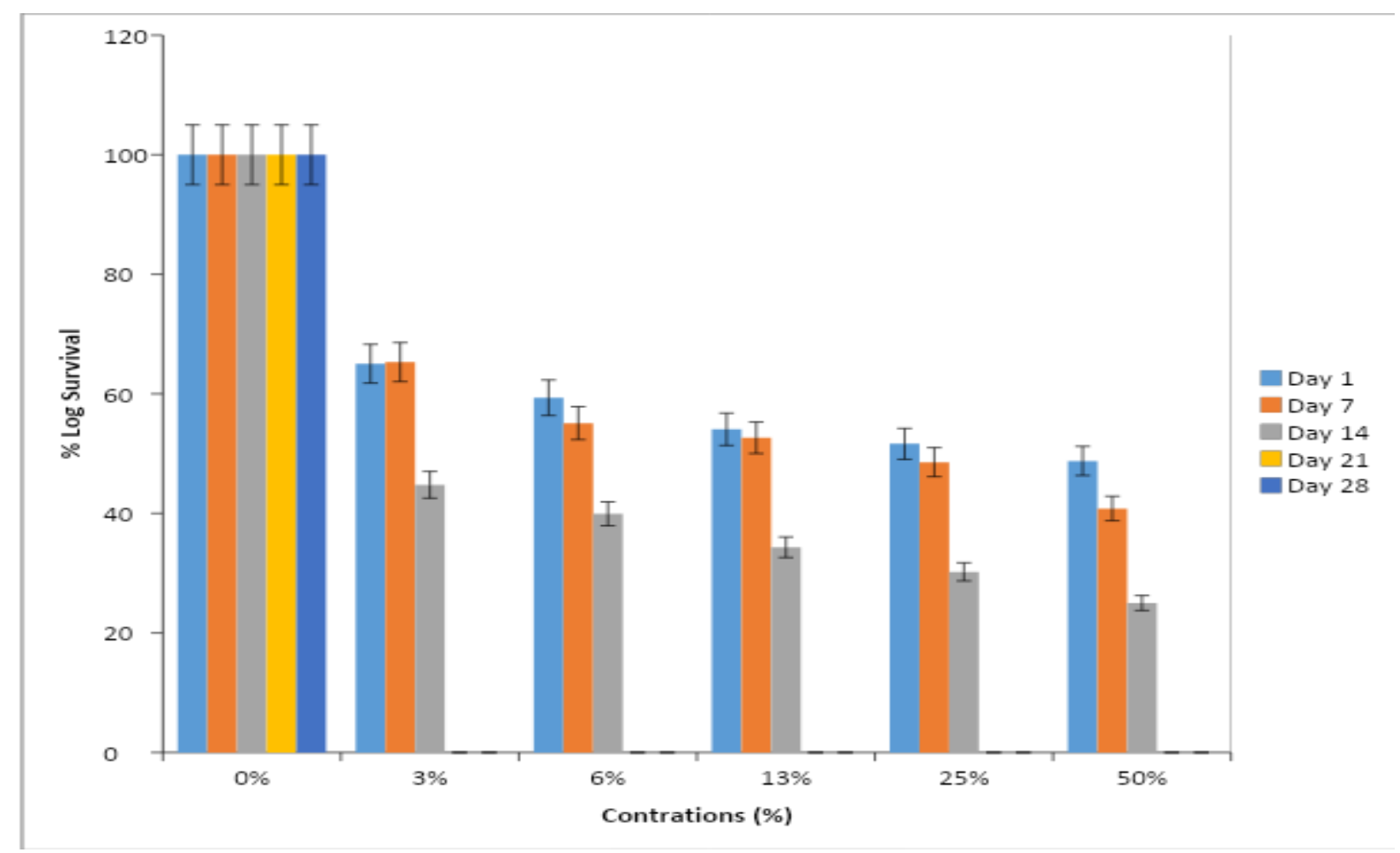

Figure.3 Percentage log survival of Bacillus species exposed to various concentrations of cyahalothrin

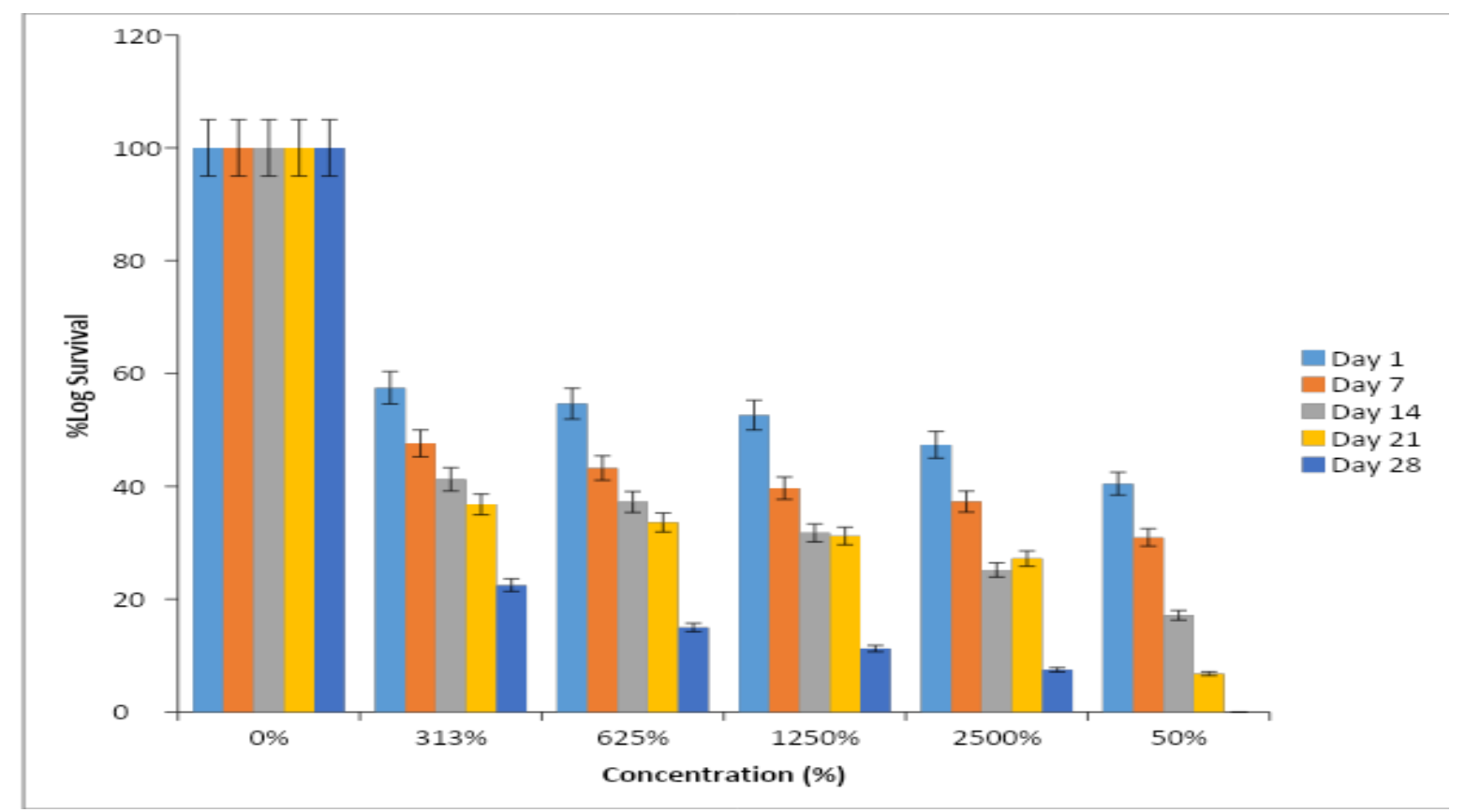


Figure.4 Percentage log survival of Bacillus species exposed to various concentrations of chlopyrifos

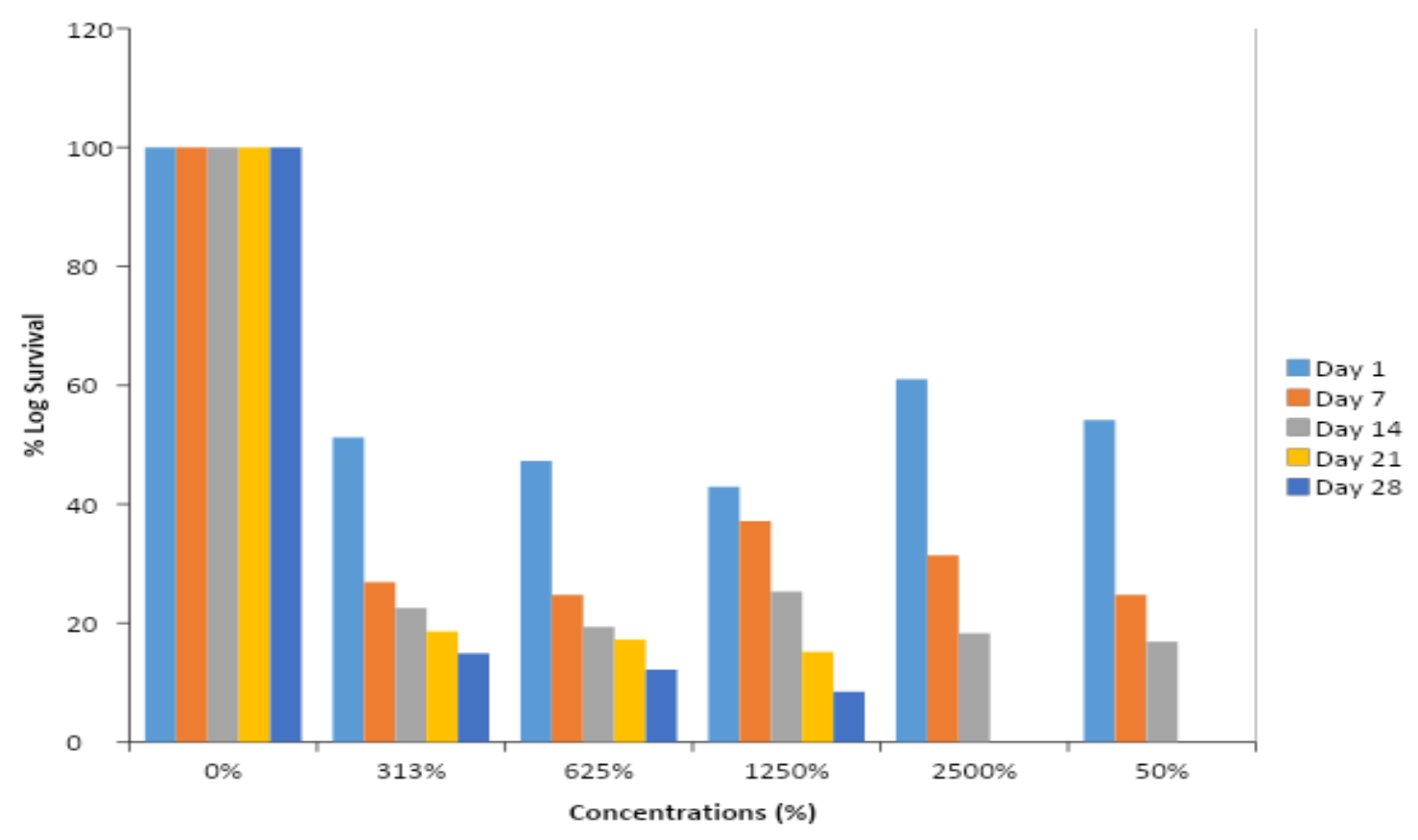

Figure.5 Median lethal concentrations of the pesticides to the test bacteria

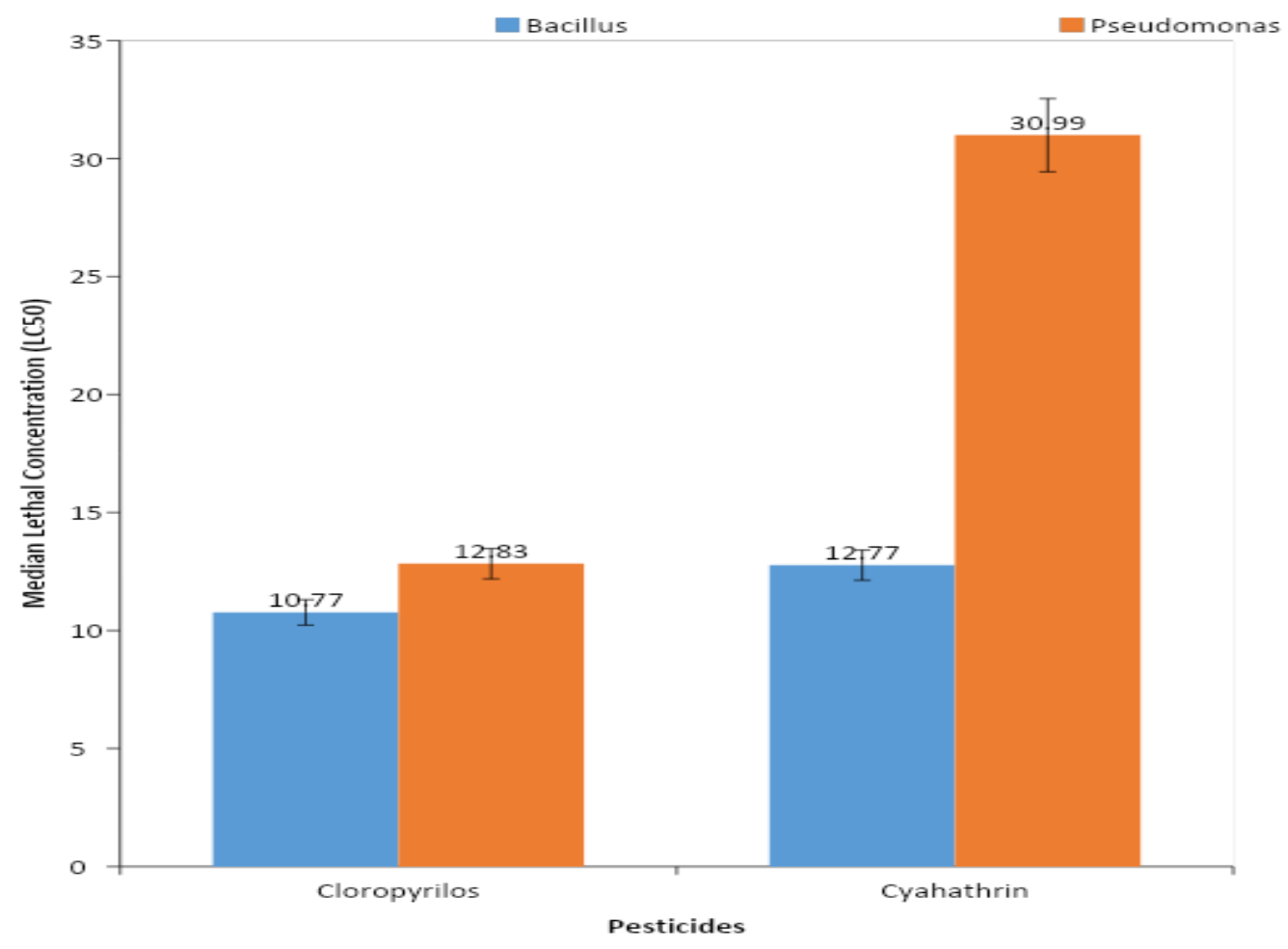


The table 3a shows the lethal toxicity of Chlorpyrifos on Psuedomonas species in soil.

The table $3 b$ shows the median lethal concentration LC50 of Chlorpyrifos from percentage mortality of Pseudomonas species in soil.

Conclusion and recommendation are given below:

The results obtained in this research work revealed that pesticides (Chlorpyrifos and Cyahalothrin) have the ability to inhibit biological processes that are mediated by key environmental microorganisms such as Bacillus and Pseudomonas species etc. in soil. Due to the effect observed on the survival rate of these organisms in this study, it indicates that these pesticides are capable of causing serious environmental pollution which will not only affect the microorganisms and their functions but also the abiotic components of the environment.

Government should set up pre-market regulation requirements, mandating chemical firms to test chemicals for their ability to kill pests so that only the pesticides that are environmentally friendly will be developed further. In this way, pesticides that are environmentally hazardous can be rejected.

Application of pesticides by farmers is as a result of lack of adequate awareness of the side effects, therefore, farmers should revert to the traditional hand hoeing, hand weeding, use of pest resistant seeds and organic farming systems. This will reduce the use of indiscriminate pesticides in the environment.

\section{References}

Andrea, M. M., Peres, T. B., Luchini, L.C. and Pettinelli, A.Jr (2000). Impact of long term pesticide application on some soil biological parameters.
Journal of Environmental Science Health B, 35, 297-307.

Belmote, A., Vega A., Garrido, F. and Martinez, L. (2005). Monitoring of Pesticides in Agriculture Water and soil samples from Andulasia by liquid chromatography couple to mass spectrometry. Analytica Chemical Acta, 53(8), 117-127.

Cheesbrough, M. (2006). District Laboratory Practice in Tropical Countries, second edition, Cambridge University press. New York.

Goodman, Brenda (21 Apr 2011). "Pesticide Exposure in Womb Linked to Lower IQ". Health \& Pregnancy. WebMD from the original on 2011-04- 24.

J R Coats (July 1990). "Mechanisms of toxic action and structure-activity relationships for organochlorine and synthetic pyrethroid insecticides". Environmental Health Perspectives. 87: 255-262.

Kpormon, L.B. and Douglas, S. I. (2018). Ecotoxicological assay of E-waste on some aquatic microflora. Journal of Advanced Biology and Biotechnology.40421, 17(2): 1- 10.

Liang-Ching, H; Ching-Yu, H; Yen-Hsun, Cand YU-Min, T (2016). Accumulation of heavy metals and trace elements in fluvial sediments received effluents from traditional and semiconductor industries. Scientific Reports 6: 34250

Lucio, G.C. (2006). Current issues in organophosphate toxicology. Clinical chemical Acta, 3666, 1-13.

Maugh II, Thomas H. (16 May 2010). Los Angeles Times. from the original on 23 April 2011.

Milidas, G.E. (1994). Determination of pesticide residues in natural water of Greece.

Miller, G.T. (2004). Sustaining the Earth 6th Edition. BrooksCole Publishing 
Company. McGraw-Hill Companies. New York.

Morello-Frosch, Rachel; Zuk, Miriam; Jerrett, Michael; Shamasunder, Bhavna; Kyle, Amy D. (May 2011). "Understanding the Cumulative Impacts of Inequalities in Environmental Health: Implications for Policy". Health Affairs. 30 (5): 879-87.

Rossberg, M. Chlorinated Hydrocarbons in Ullmann's Encyclopedia of Industrial Chemistry 2006, Wiley-VCH, Weinheim.

Offiong, R. A.; Atu, J. E.; Njar, G. N. and Iwara, A. I. (2009). Effects of Land Use Change on Soil Physico-chemical Properties in a south-southern Nigeria. African Journal of Environment, Pollution and Health, 7(2):47-51.

Ogbonna, D.N (2014). Distribution of microorganisms in water, soils and sediment from abattoir wastes in Southern Nigeria. Int. Journal of Current Microbiology Applied Science, 3, 1183-1200.

Peter, J. V.; Sudarsan, T. I.; Moran, J. L. (2014). "Clinical features of organophosphate poisoning: A review of different classification systems and approaches". Indian Journal of Critical Care Medicine. 18 (11): $735-$ 745.

Rainer, M.M., Lan, L.P. and Gerba, C.P. (2009). Environmental Microbiology, 2nd Ed. Academic Press. USA.
Robert L. Metcalf "Insect Control" in Ullmann's Encyclopedia of Industrial Chemistry Wiley-VCH, Wienheim, 2002.

Soderlund, David M; Clark, John M; Sheets, Larry P; Mullin, Linda S; Piccirillo, Vincent J; Sargent, Dana; Stevens, James T; Weiner, Myra L (2002-0201). "Mechanisms of pyrethroid neurotoxicity: implications for cumulative risk assessment". Toxicology. 171 (1): 3-59.

Wesseling, C. vanWendeldeJoode, B., Ruepert, C., Leon, C., Monge, P., Hermosillo, H. and Partanen, T (2001). Paraquat in developing countries. International Journal of Occupation and Environmental Health, 7, 275-286.

WHO. (2009). Recommended Classification of Pesticides by Hazard and guideline to classification. http://www.int? ipcs?publications?pesticideshazard?en . Accessed on 14th August, 2013.

Williams, J. O. and Dilosi, L. B. (2018) Response of Chemolithotrophic Nitrobacter, Nitrosomonas to Toxicity of Organophoshphate and Pyrethroid Pesticides. Asian Journal of Biology, 7(1): $1-8$.

Williams, J.O. and Ogolo, C.N. (2018). Response of Aspergillus species to the toxicity of domestic detergents. Nigerian journal of Microbiology, 32(1), 4334-4343.

\section{How to cite this article:}

Williams, Janet Olufunmilayo, Chibuike, Princess Mebom and Etim, Blessing Henry. 2020. Tolerance of Pseudomonas and Bacillus spp. to Cyahalothrin and Chlorpyrifos Pesticides. Int.J.Curr.Microbiol.App.Sci. 9(04): 3162-3173. doi: https://doi.org/10.20546/ijcmas.2020.904.368 